\title{
MIEJSCA ZSYŁEK BISKUPÓW WSCHODNIORZYMSKICH W IV I V WIEKU
}

Zjawiskiem, które zdominowało późną starożytność, była rywalizacja w łonie chrześcijaństwa, zwaśnionych części Kościoła. Jednym z elementów tej rywalizacji było doprowadzanie do depozycji biskupów z przeciwnej strony ${ }^{1}$. Depozycja była narzędziem, po które chętnie sięgali zwalczający się duchowni, szczególnie w okresie kontrowersji ariańskiej: była ona najskuteczniejszym sposobem odebrania tronu biskupiego swemu przeciwnikowi. By jednak do niej doprowadzić, należało wystąpić z zarzutami obciążającymi danego biskupa. W obliczu częstego braku możliwości rozsądzenia zasadności tych zarzutów, pozostaje tylko dociekać, jakie czynniki w poszczególnych przypadkach zadecydowały o depozycji bądź o wygnaniu danego biskupa. Zwalczające się strony sięgały po przeróżne zarzuty, posądzając swych przeciwników również o ciężkie przewinienia. Biskupi byli pozbawiani swych tronów na skutek opowiadania się za stroną aktualnie będącą w mniejszości w Kościele lub też wtedy, kiedy nie chcieli odstąpić od wyznania wiary zwalczanego przez cesarza. Depozycje zasądzano również wobec biskupów, którym udowodniono niemoralne prowadzenie się, a także wobec tych, którzy splamili się symonią, tymborychią, lichwą itd.

Biskupów pozbawionych urzędów starano się izolować od ich dotychczasowego środowiska. Byli oni wyłączani z Kościoła, zakazywano tytułować ich biskupami oraz kontaktować się z nimi ${ }^{2}$. W wielu przypadkach doprowadzenie do depozycji tego, czy innego biskupa, było tylko preludium: środkiem ostatecznym służącym wyeliminowaniu wpływu konkretnego biskupa na bieg spraw w Kościele było doprowadzenie do jego zesłania. O ile o depozycji tego czy innego biskupa wyrokowali sami dostojnicy kościelni obradujący na sobo-

${ }^{1} \mathrm{~W}$ niniejszym artykule interesować nas będą przypadki zsyłek biskupów wschodniorzymskich, mające miejsce do połowy $\mathrm{V}$ wieku.

${ }^{2}$ Por. Sozomenus, HE III 12, PG 67, 1064-1065, t1. S. Kazikowski (Hermiasz Sozomen, Historia Kościota, Warszawa 1989), s. 171-173. 
rach lub synodach ${ }^{3}$, to decyzja o zesłaniu na wygnanie zdeponowanego biskupa należała już do cesarza ${ }^{4}$.

Należałoby więc zastanowić się, jakie czynniki decydowały o tym, iż ten czy inny pasterz trafiał na wygnanie; można dopatrzeć się tu bowiem pewnych prawidłowości. Na zsyłkę trafiali, poza kilkoma wyjątkami, przede wszystkim wpływowi pasterze wielkich miast, takich jak Konstantynopol, Aleksandria czy Antiochia. Decydowało o tym jednak wiele czynników. Z opisu rozruchów, do jakich dochodziło na skutek depozycji biskupów, rozmiaru poparcia, jakim cieszyli się oni w swych miastach czy też w ówczesnym Kościele, wynika, iż skazanie na zsyłkę było optymalnym posunięciem mającym zagwarantować trwałe przejęcie tronu biskupiego przez przeciwników obalonego biskupa. Zsyłka na wygnanie była również jednym ze sposobów mających służyć uspokojeniu nastrojów w poszczególnych Kościołach. Faktem jednak jest, iż samo wywożenie zdeponowanego biskupa na wygnanie bywało (najczęściej w wielkich miastach) przyczyną rozruchów trwających czasami po kilkanaście dni. Pozostawienie zaś popularnego pasterza swojemu losowi lub nawet zamknięcie go w klasztorze czy też zakazanie mu opuszczania swego miejsca zamieszkania ${ }^{5}$, było tyleż niebezpieczne, co i niewygodne dla ich następców.

\section{PRZYCZYNY WYGNANIA}

Na wygnanie w końcu IV wieku skazywano głównie tych biskupów, którzy nie chcieli porzucić nauki Ariusza ${ }^{6}$. Czasami zsyłka groziła również tym biskupom, którzy mimo wyraźnego rozporządzenia cesarza zignorowali jego wezwanie do udziału w soborach lub synodach ${ }^{7}$. Na wygnanie skazywano też

${ }^{3}$ Zdarzały się jednak w tej mierze i nadużycia: Teodojusz II w 449 r. nakazał (Codex Iustinianius I, tit. 1, c. 3 /3/, ed. Th. Mommsen, Berolini 1873; Evagrius, HE I 12, tł. S. Kazikowski (Ewagriusz Scholastyk, Historia Kościoła, Warszawa 1990, s. 22), aby wszyscy stronnicy Nestoriusza zostali usunięci ze swych kościołów. Podobnie cesarz Bazyliskos nakazał odebrać trony biskupie chalcedończykom (Evagrius, HE III 4).

${ }^{4}$ Tu również dochodziło do nadużyć ze strony duchownych, o czym poniżej.

${ }^{5}$ Por. Sozomenus, HE IV 26; Socrates, HE II 38, tł. S. Kazikowski (Sokrates Scholastyk, Historia Kościoła, Warszawa 1986, s. 198-203), (przykład biskupa Konstantynopola Macedoniusza, adwersarza Pawła). W tej kwestii por. także R. Klein, Constantius der II und die christliche Kirche, Darmstadt 1977, s. 94-95.

${ }^{6}$ Por. chociażby sprawę Demofila, biskupa Konstantynopola wygnanego w 380 roku (Socrates, HE V 7; Sozomenus, HE VII 5; Theophanes, Chronographia, AM 5873, ed. and transl. by C. Mango, R. Scott, Theophanes, Chronicle. Byzantine and Near Eastern History ad 284-813, Oxford 1997). W czasach Teodozjusza I i jego następców wydano wiele rozporządzeń nakazujących przeganianie $\mathrm{z}$ miast duchownych heretyckich, czasami do miejsc, z których pochodzili, por. m.in. CTh XVI 5, 12, 30, 31, 32, 33, 34, 36.

${ }^{7}$ Por. np. rozporządzenie Konstancjusza II zwołujące biskupów na obrady do Tyru (Theodoretus, HE I 29). 
stronników pasterzy wielkich biskupstw, bez względu na to, jaka była przyczyna potępienia ich metropolity czy też patriarchy ${ }^{8}$. Na wygnanie trafiali także niektórzy biskupi, których działalność zdawała się mącić porządek w Kościele, jak to było chociażby w przypadku biskupa aleksandryjskiego Dioskura (444-451); do upadku Dioskura przyczynił się zresztą sam cesarz Marcjan, który nie chciał zbytniego wzmocnienia pozycji Aleksandrii wśród Kościołów Wschodu ${ }^{9}$. Na zsyłkę trafiali również ci biskupi, których postępowanie mogło zagrażać sprawowaniu rządów tego czy innego władcy ${ }^{10}$, biskupi, których ordynacja była nie po myśli cesarzy ${ }^{11}$.

Biskupi trafiali na wygnanie bądź też z niego powracali często w związku ze zmianą panującego. Tak było chociażby w przypadku Atanazego skazanego na pierwsze wygnanie przez Konstantyna Wielkiego, a którego z wygnania odwołał Konstantyn $\mathrm{II}^{12}$. Z drugiego wygnania Atanazego odwołał cesarz Konstans $^{13}$. Wygnanym przez Kontancjusza II biskupom pozwolił na powrót do swych siedzib cesarz Julian ${ }^{14}$. Natomiast jego następca Jowian odwołał z wygnania tych duchownych, którzy trafili tam z wyroku Juliana ${ }^{15}$. Walens zaś rozkazał powrócić na wygnanie wszystkim tym biskupom, którzy ponownie objęli swe trony po odwołaniu ich z wygnania przez Juliana ${ }^{16}$, a według Teo-

${ }^{8} \mathrm{~W}$ tym przypadku przykładów można by podać wiele, o większości z nich będzie mowa w dalszej części artykułu.

${ }^{9}$ Por. Theophanes, Chronographia, AM 5944; Evagrius, HE II 4; S. Bralewski, Imperatorzy późnego Cesarstwa Rzymskiego wobec zgromadzeń biskupów, Łódź 1997, s. 166-167.

${ }^{10}$ Por. np. przypadek biskupa Antiochii Eudoksjosa, wygnanego przez Konstancjusza II za jego powiązania z cezarem Gallusem (Philostorgius, HE IV 8) oraz sprawa Atanazego i jego rzekomych zamiarów przerwania dostaw zboża z Egiptu (por. Socrates, HE I 35; Athanasius, Apologia contra arianos 9, 87; Photius, Bibliotheca cod. 258); zob. też: C.J. Hefele, Conziliengeschichte, Bd. I, Freiburg im Breisgau 1855, s. 673; E. Wipszycka, Aleksandryjscy biskupi i cesarskie rozdawnictwa zboża, ,Przegląd Historyczny” 87(1996) 407-408.

11 Por. przykład Pawła (337-339), biskupa Konstantynopola (Sozomenus, HE III 3; Socrates, HE II 7) lub Jana (482), następcy Tymoteusza Salokafialosa (460-482), ordynowanego wbrew opinii Zenona na urząd biskupi w Aleksandrii (Evagrius, HE III 12).

${ }^{12}$ Por. Theodoretus, HE II 1- 2; Athanasius, Apologia contra arianos 87; Socrates, HE II 3; Sozomenus, HE III 2; zob. także M. Simonetti, La crisi ariana nel IV secolo, Roma 1975, s. 137-139; J. Gliściński, Wspótistotny Ojcu, Łódź 1992, s. 52.

13 Por. Socrates, HE II 22-23; Sozomenus, HE III 20; Philostorgius, HE III 12; Theodoretus, HE II 8; Rufinus, HE I 19; R.P.C. Hanson, The Search for the Christian Doctrine of God. The Arian Controversy 318-381, Edinburgh 1988, s. 307-308.

${ }^{14}$ Por. Rufinus, HE I 27; Ammianus Marcellinus, Res Gestae, XXII 5, 3; Theophanes, Chronographia, AM 5853; Socrates, HE III 4-5; Sozomenus, HE V 5; Theodoretus, HE III 4; Photius, Bibliotheca cod. 258. Do swych siedzib powrócili wówczas m.in.: Atanazy (do Aleksandrii), Melecjusz (do Antiochii) oraz biskupi Zachodu zesłani przez Konstancjusza II do Tebaidy: Euzebiusz (do Vercelli), Hilary (do Poitiers) oraz Lucyfer (do Cagliari).

${ }^{15}$ Por. Theophanes, Chronographia, AM 5856; Theodoretus, HE IV 2 (odwołanie Atanazego).

${ }^{16}$ Por. Theodoretus, HE IV 13. 
fanesa również przez Jowiana ${ }^{17}$. Cesarz Gracjan natomiast po śmierci Walensa (choć mógł dokonać tego jeszcze sam Walens) odwołał z wygnania wszystkich biskupów zesłanych tam przez swego współrządcę ze Wschodu ${ }^{18}$. Teodozjusz II odwołał z wygnania zwolenników Jana Chryzostoma, których na zsyłkę skazał jego poprzednik, cesarz Arkadiusz. Natomiast następca Teodozjusza II, Marcjan z wygnania odwołał między innymi biskupa Cyru Teodoreta, Ibasa, biskupa Edessy oraz być może Nestoriusza (który zmarł w drodze powrotnej), jak utrzymuje Zachariasz Retor ${ }^{19}$, choć inne przekazy wydają się przeczyć temu. Z chwilą, kiedy w 476 roku władzę w cesarstwie wschodniorzymskim objął Zenon, na wygnanie poszli Piotr - biskup Aleksandrii i Paweł - biskup Efe$\mathrm{zu}$, piastujący swe urzędy z przyzwolenia jego poprzednika, cesarza Leona ${ }^{20}$ (457-474) oraz ci (np. Tymoteusz Kot), którzy odzyskali swe trony w czasie uzurpacji Bazyliskosa ${ }^{21}$. Przypadki tego typu można by mnożyć.

Należałoby podjąć próbę odpowiedzi na pytanie, kto stał za decyzjami skazującymi biskupów na wygnanie? W przeważającej mierze decyzja ta była skutkiem zabiegów ich kościelnych przeciwników ${ }^{22}$ oraz nalegań urzędników prowincjonalnych $^{23}$, którzy w wywiezieniu pozbawionego swego tronu biskupa upatrywali możliwość uspokojenia nastrojów w miastach. Któż bowiem w interesującym nas okresie kierował polityką religijną państwa? Bardziej doradcy cesarscy niż sam cesarz, doradcy, do których każdy miał dostęp, także biskupi oraz ich przyjaciele, często również piastujący wysokie funkcje w państwie ${ }^{24}$. Nie można oczywiście nie doceniać osobistego zaangażowania w politykę religijną poszczególnych władców, jak Konstancjusza II, Juliana czy Walensa, lecz również oni polegali w tej mierze głównie na opinii swych doradców. Jeśli depozycje zasądzane były względem duchownych ortodoksyjnych w okresie

17 Por. Theophanes, Chronographia, AM 5857; 5861. Teofanes utrzymując, iż na wygnanie mieli pójść również biskupi odwołani przez Jowiana, być może miał na myśli przypadek Atanazego, którego Jowian rzeczywiście odwołał z wygnania, na które skazał go Julian.

${ }_{18}$ Por. Theophanes, Chronographia, AM 5871; Theodoretus, HE, V 2.

${ }_{19}$ Por. Zacharias Rhetor HE III 1 i II 2; Evagrius, HE III 4.

${ }^{20}$ Por. Vita Petri Iberi 81; zob. Petrus der Iberer. Ein Charakterbild zur Kirchen - und Sittengeschichte des fünften Jahrhunderts, hrsg. von R. Raabe, Leipzig 1895.

${ }_{21}$ Por. Evagrius, HE III 4; 11; Zacharias Rhetor, HE V 2; zob. także Vita Petri Iberi 80.

${ }^{22} \mathrm{~W}$ tym przypadku można by podać wiele przykładów, o większości z nich będzie mowa w niniejszym artykule. W literaturze nie mówi się np. o biskupach, którzy utracili swe trony na skutek zabiegów Nestoriusza. W Sinodicon (PG 84, 803-804) natomiast odnajdujemy listę zdeponowanych za sprawą Nestoriusza biskupów, jak: Aleksander - biskup Hierapolis, Abbibus (Dolichium), Melecjusz (Mopsuestia). Wielu innych miało „dobrowalnie” zrezygnować z pełnienia funkcji biskupich, jak: Zenobiusz (Zephyrium), Eutheriusz (Tyana), Anastazjusz (Tenedos), Pausianus (Hypata), Bazyli (Larissa), Julian (Sardica), Teodozjusz (Kios), Acilinus (Barbalissos), Maximius (Demetrias).

${ }^{23}$ Por. chociażby sprawa Eunomiusza (Philostorgius, HE IX 1; 8).

${ }^{24}$ Por. M.B. Leszka, Rola duchowieństwa na dworze cesarzy wczesnobizantynískich, Łódź 2000, s. 49; 99. 
rządów Konstancjusza II czy też Walensa, wówczas były one w przeważającej mierze równoznaczne skazaniu na wygnanie. Generalnie jednak pozbawienie biskupa tronu nie było równoznaczne ze skazaniem go na wygnanie.

W czasach Juliana na wygnanie szli biskupi, którzy wcześniej gorliwie tępili pogaństwo, jak chociażby Tytus, biskup Bostry ${ }^{25}$ oraz Atanazy ${ }^{26}$. Ze swych tronów byli zrzucani, a potem zsyłani na wygnanie, także ci spośród biskupów, którzy mimo cesarskich nalegań nie zgadzali się z wyrokiem skazującym konkretnego duchownego na depozycję ${ }^{27}$, lub ci, którzy wystąpili przeciwko biskupom aktualnie popieranym przez cesarza ${ }^{28}$. W czasach kontrowersji ariańskiej na wygnanie szli również pasterze, którzy mimo nalegań nie chcieli przystąpić do partii ariańskiej ${ }^{29}$. Zdarzały się wypadki, aczkolwiek bardzo sporadycznie, kiedy władcy popierający arianizm zostawiali na tronach duchownych ortodoksyjnych nawet w wielkich miastach. Tak było między innymi z Paulinem, jednym z dwóch (drugim był Melecjusz) ortodoksyjnych biskupów Antiochii. Jak bowiem twierdzi Sozomen, cesarz Konstancjusz nie odważył się zesłać Paulina na wygnanie ze względu na ,jego wiek” i „świętość życia" ${ }^{30}$. Znane są nam dwa przypadki, kiedy biskupi trafiali na wygnanie bez wiedzy cesarza. Przykładem takich nadużyć jest działalność biskupa Ancyry Bazylego, który w 359 roku wykorzystując do tego lokalnych urzędników zesłał na wygnanie 70 biskupów Galacji ${ }^{31}$. Według Filostorgiusza, Bazyli w swym działaniu wspierany był przez damy z dworu cesarskiego. Kiedy cesarz Konstancjusz II dowiedział się o tych wydarzeniach, odwołał z wygnania biskupów wypędzonych przez Bazylego ${ }^{32}$.

Czasami biskupi, w sprawie których zapadł już wyrok skazujący ich na wygnanie, próbowali bezpośrednio odwoływać się od tej decyzji do cesarza, lub też w imieniu swego pasterza podążała do cesarza delegacja lokalnej społeczności ${ }^{33}$. Niekiedy sprawę próbowano załatwić u lokalnych urzędników, jak

${ }^{25}$ Por. Sozomenus, HE V 15; Socrates, HE III 13; Theophanes, Chronographia, AM 5854.

${ }^{26}$ Por. Theophanes, Chronographia, AM 5854; Julianus Imperator, Epistulae 6 et 51; Theodoretus, HE, III 10.

27 Por. Athanasius, Apologia ad Constantium imperatorem 27.

28 Por. przykład biskupów przybyłych do cesarza Walensa chcących zapoznać go z uchwałami synodu w Lampsakos (Sozomenus, HE VI 7).

${ }^{29}$ Por. chociażby Sozomenus, HE VI 8.

${ }^{30}$ Por. Sozomenus, HE VI 7.

${ }^{31}$ Por. Philostorgius, HE IV 8; C. J. Hefele, op. cit., Bd. I, s. 673; zob. także T. D. Barnes, The Crimes of Basil of Ancyra, JTS 47(1996) 550-554 oraz M. Stachura, Heretycy, schizmatycy i manichejczycy wobec cesarstwa rzymskiego (lata 324-428, wschodnia część Imperium), Kraków 2000, s. 72.

${ }^{32}$ Por. Philostorgius, HE IV 10.

33 Por. Athanasius, Apologia ad Constantium imperatorem 24; idem, Apologia contra arianos 86; zob. także H. Drake, Athanasius’ First Exile, „Greek, Roman and Byzantine Studies” 27(1986) s. 194; T.D. Barnes, Athanasius and Constantius. Theology and Politics in the Constantinian Empire, London 1993, s. 23-24. 
to było w przypadku Atanazego w 365 roku, kiedy to cesarz Walens zarządził, aby wszyscy biskupi wygnani przez Konstancjusza II, a odwołani z wygnania przez Juliana, powrócili na miejsca zsyłki ${ }^{34}$. Rozporządzenie to, jak powszechnie wówczas uważano, wydane zostało $\mathrm{z}$ inicjatywy duchownych ariańskich, chcących odzyskać utracone biskupstwa na skutek poczynań Juliana i Jowia$\mathrm{na}^{35}$. Trudno jednak powiedzieć, ilu dokładnie ortodoksyjnych biskupów poszło na wygnanie w czasach Konstancjusza II i Walensa ${ }^{36}$.

Często również sami biskupi (jak na przykład Atanazy) nie mieli zamiaru podporządkować się decyzji ces̉arskiej skazującej ich na wygnanie i nie chcieli opuścić swych siedzib ${ }^{37}$. Stan taki mógł trwać przez pewien czas, jeśli biskup, który nie chciał podporządkować się wyrokowi wygnania, miał za sobą wielu stronników. W takich przypadkach również dowódcy wojskowi, którzy mieli obowiązek dostarczyć biskupa do miejsca wygnania, niewiele mogli zdziałać wiedząc, że próba pochwycenia biskupa i wywiezienie go z miasta może zakończyć się poważnymi rozruchami. Jeśli stan taki przeciągał się, wówczas chrześcijanie $\mathrm{z}$ przeciwnego odłamu albo sami tropili ukrywającego się skazańca ${ }^{38}$, albo też o tej sytuacji donosili cesarzowi ${ }^{39}$. Wielu też biskupów nie chcąc podporządkować się decyzji skazującej ich na wygnanie utrzymywało, iż nie jest to decyzja wydana przez cesarza lecz przez lokalnych urzędników działających wspólnie $\mathrm{z}$ arianami. $\mathrm{Z}$ taką sytuacją mamy na przykład do czynienia chociażby w przypadku czwartego wygnania Atanazego, który oczekując na pisemną decyzję cesarską dotyczącą jego wygnania, ukrywał się w Aleksandrii aż przez 26 miesięcy ${ }^{40}$.

Nie zawsze pokojowa atmosfera towarzyszyła opuszczeniu miasta przez skazanego na wygnanie biskupa. Najczęściej dochodziło wówczas do poważnych rozruchów. Faktem jest jednak, iż źródła opisują głównie wygnanie pasterzy wielkich miast, którzy cieszyli się poparciem sporych rzesz wiernych. Rozruchy, do jakich wówczas dochodziło, w naszej opinii były najczęściej nie

${ }^{34}$ Por. Sozomenus, HE VI 12.

35 Ibidem, VI 12.

${ }^{36}$ Atanazy (De fuga sua 3), stwierdza, iż oszczerstwa i intrygi arian w czasach Konstancjusza II poprowadziły na wygnanie wielu biskupów. Teodoret natomiast (HE IV 12-13); HR II 15= Dzieje miłości Bożej. Historia mnichów syryjskich, ŹM 7, tł. K. Augustyniak, Kraków 1994, s. 92) informuje, iż w czasach Walensa z wielu miast wypędzono ich pasterzy.

${ }^{37}$ Por. Athanasius, Apologia ad Constantium imperatorem 19.

38 Por. Idem, De fuga sua 24; Photius, Bibliotheca cod. 258.

${ }^{39}$ Por. Athanasius, Apologia ad Constantium imperatorem 32.

${ }^{40}$ Ibidem, c. 22, 24, 26. Podobna sytuacja miała miejsce w przypadku rozporządzenia Teodozjusza II, kiedy to cesarz nakazał biskupowi Cyru Teodoretowi, nie opuszczać swego miasta pod jakimkolwiek pozorem. Teodoret podejrzewając, iż nie jest to decyzja cesarska, a jedynie kolejny z wybiegów jego przeciwków chcących zatrzymać go w Cyrze, wysyła do swych przyjaciół w stolicy listy z prośbą, aby ci dowiedzieli się, czy cesarz rzeczywiście wydał taką decyzję (Theodoretus, Epistolae 79-81). 
tyle następstwem nie kontrolowanego rozwoju wydarzeń, lecz zamierzonym skutkiem działań zainteresowanej strony. Niekiedy byli to ortodoksi, którzy groźbą buntu miejskiego szachowali prefektów; czasami inicjatywa mogła wychodzić od arian, którzy wywołując zamieszki chcieli dodatkowo zdyskredytować wygnańca rozgłaszając, iż zamieszki wywołali stronnicy skazanego biskupa lub nawet on sam nie chcąc opuścić miasta. W każdym razie problem odpowiedzialności skazywanych na wygnanie biskupów za wywoływanie przez nich zamieszek jest obecny w ustawodawstwie IV wieku, gdzie ustawodawca, a więc cesarz, wyraźnie stwierdza, iż inspiratorami tych niepokojów byli sami dostojnicy kościelni lub ich poplecznicy działający na rzecz swych pasterzy ${ }^{41}$.

Czasami skazywani na wygnanie biskupi nie chcąc być obwiniani o wywołanie zamieszek w miastach, które opuszczali, decydowali się na rychłe, najczęściej nocne, opuszczenie miasta. Wielu biskupów zostało też wywabionych ze swych miast podstępem, jak na przykład Paweł, biskup Konstantynopola ${ }^{42}$. Rozruchy towarzyszyły wychodzeniu na wygnanie Atanazego, biskupa Konstantynopola Pawła, Jana Chryzostoma oraz Tymoteusza Kota. Dlatego też urzędnicy mający wywieźć biskupa z miasta, zapewniali sobie zbrojną eskortę. W przypadku Aleksandrii były to najczęściej oddziały wojskowe ściągane w tym celu z Egiptu albo z Libii ${ }^{43}$. Podobne rozmiarami zamieszki towarzyszyły również elekcjom biskupim w wielu miastach rzymskiego Wschodu. Czasami władcy chcąc uspokoić nastroje w mieście, gotowi byli do odwołania ze zsyłki wygnanego biskupa. Tak było chociażby w przypadku ostaniego wygnania Atanazego, kiedy to Walens na skutek braku możliwości uspokojenia nastrojów w Aleksandrii oraz niepewnej sytuacji politycznej w państwie, spowodowanej uzurpacją Prokopiusza, zmuszony był odwołać go z wygnania ${ }^{44}$.

\section{DROGA NA WYGNANIE}

Najczęściej jednak udawało się odstawić deponowanych biskupów na miejsce ich wygnania. W źródłach późnoantycznych odnajdujemy opisy przebywanej przez nich drogi na wygnanie. Najwcześniej powstałą relacją jest opis wygnania biskupów egipskich i libijskich autorstwa Atanazego. Według niego, biskupów tych, nierzadko już leciwych pasterzy, spętanych gnano do Wielkiej Oazy. Byli to w większości duchowni, ordynowani jeszcze przez jego poprzednika Aleksandra, którzy również podobnych prześladowań doświadczyli od pogańskich cesarzy. Atanazy akcentuje, iż z racji wieku wygnańców ariańskim

\footnotetext{
${ }^{41}$ CTh XVI 2, 35 (rok 400 i 405).

${ }^{42}$ Sozomenus, HE III 9 (drugie wygnanie Pawła).

${ }^{43}$ Por. między innymi: ibidem, IV 9.

44 Ibidem, VI 12; Socrates, HE IV 13.
} 
prześladowcom zależało nie tylko na pozbawieniu ortodoksów swych siedzib, lecz także mieli oni nadzieję, iż leciwi już kapłani nie wytrzymają trudów podróży przez pustynię i w drodze na wygnanie umrą z wycieńczenia ${ }^{45}$. Takie przypadki rzeczywiście miały miejsce ${ }^{46}$. Daleka droga, jaką przebyć musieli skazańcy, przynosiła jednak według Atanazego nieoczekiwany przez arian efekt. Mianowicie, im dłużej biskupi szli, tym większym rzeszom chrześcijan mogli wyjaśniać sedno sporu, potępiając tym samym arian i stosowane przez nich metody ${ }^{47}$.

Pasterze pokroju Atanazego, udawali się na wygnanie w towarzystwie sporego orszaku ${ }^{48}$. Można poza tym przypuszczać, iż duchowni skazani na wygnanie starali się niekiedy nadać swej wędrówce męczeński charakter. Na zsyłkę z bardziej znaczącymi biskupami podążali ich dotychczasowi zaufani kapłani, zwolennicy tymczasowo przegranej sprawy, których obecność przy nowo ustanowionym biskupie $\mathrm{z}$ pewnością była niepożądana. Czasami jednak kapłani obalonego biskupa trafiali na wygnanie w zupełnie inne miejsce niż ich pasterz ${ }^{49}$.

Opis drogi na zsyłkę pozostawił nam również Palladiusz, przedstawiając poniewierkę Chryzostoma i jego stronników. Pędzeni na wygnanie w ciągu jednego dnia mieli pokonywać drogę, na przebycie której potrzebowano normalnie dwóch dni ${ }^{50}$. Wielu spośród pasterzy miast, przez które przechodził transport z biskupami, wychodziło im naprzeciw oferując gościnę. Tak miało być między innymi w przypadku transportu biskupów, w którym do Egiptu podążał sam Palladiusz. Gościnność swą mieli też okazać biskupi kapadoccy: Teodor z Tyany, Bosporiusz z Kolonei oraz Serapion, biskup egipskiego Ostrakine $^{51}$.

Wiadomość o pędzonych na wygnanie biskupach wyprzedzała zazwyczaj ich pochód o kilka dni. Często więc w miejscowościach, przez które przechodzili, eskortujący ich żołnierze nalegali, aby wygnańcy udawali się do miejscowych pasterzy z prośbą o wsparcie pieniężne, które to później żołnierze odebrawszy im przepuszczali w gospodach (zamykając biskupów na ten czas - jak to stwierdza Palladiusz - chociażby w opuszczonych synagogach $)^{52}$. Jak nato-

45 Athanasius, Historia Arianorum 71; idem, Apologia ad Constantium imperatorem 32.

46 Idem, De fuga sua 7; idem, Historia Arianorum 71.

47 Idem, Historia Arianorum 34.

48 Idem, Apologia contra arianos 86.

49 Kapłani aleksandryjscy, stronnicy Atanazego w 339 roku poszli na wygnanie do Armenii (Athanasius, Historia Arianorum 21). Według Palladiusza (Dialogus de vita Joannis Chrysostomi 20,68) na wygnanie do Palestyny, Arabii, Mezopotamii, Pontu, Kapadocji i Tebaidy trafili kapłani deponowanych stronników Chryzostoma. Jednemu z kapłanów Jana o imieniu Stefan, udało się nawet zbiec z takiego transportu, kiedy Izauryjczycy napadli na eskortujący go oddział wojskowy (ibidem, 20, 72-74). Wielu duchownym Jana udało się też zbiec na Zachód (ibidem).

${ }^{50}$ Por. Dialogus 20, 120-123.

${ }^{51}$ Ibidem, 20, 173-179.

52 Ibidem, 20, 124-127. 
miast reagowali na przybywających do miast wygnańców stronicy Teofila? Najczęściej płacili oni żołnierzom pieniądze, aby ci pośpiesznie opuścili ich miasta. Wśród tak postępujących Palladiusz wymienia biskupów Tarsu, Antiochii i Cezarei Palestyńskiej. Natomiast inni stronnicy Teofila, jak na przykład Leoncjusz, biskup Ancyry (którego wrogości doświadczył również Chryzostom, o czym poniżej) oraz Amonios, biskup Peluzjum, nie tylko ofiarowali żołnierzom pieniądze, aby ci czym prędzej opuszczali ich miasta, lecz również zabraniali swym wiernym goszczenia wygnańców w swych domach lub wspierania ich jałmużną ${ }^{53}$.

Palladiusz pozostawił nam również opis poniewierki Chryzostoma. W tym przypadku jednak najlepiej będzie, jeśli głos oddamy samemu Janowi. Z jego zaś korespondencji wynika, że rozpuszczano pogłoski (kiedy przebywał on pod strażą w Nicei), iż na miejsce jego wygnania wybrano Sebaste, stolicę Armenii II. Dlatego też jeden z jego przyjaciół bliżej nie znany nam Arabios proponował, aby Jan na wygnaniu zamieszkał w jego sebasteńskiej willi ${ }^{54}$. Wybór Kukuzus na miejsce zesłania był jednak zaskoczeniem dla Jana: mała nadgraniczna miejscowość z niewielkim garnizonem wojskowym, mającym chronić tę część Armenii przed najazdami Izauryjczyków, była miejscem, gdzie kłopotliwe było nawet zakupienie żywności ${ }^{55}$. Jan po dwumiesięcznym pobycie w Nicei wyruszył w końcu do Kukuzus ${ }^{56}$. Ludzie, których napotykał przejeżdżając przez Galację, mieli witać go z płaczem i współczuciem, iż przypadł mu w udziale taki $\operatorname{los}^{57}$. Już wówczas dochodziły do niego listy od jego stronników z Konstantynopola, które przynajmniej na krótko poprawiały mu nastrój ${ }^{58}$. Jan stwierdzal, iż był dobrze traktowany przez eskortujących go żołnierzy ${ }^{59}$. Zaprzyjaźnił się nawet z samym dowódcą transportu, bliżej nam nie znanym Teodorem, który to powracjąc do stolicy przywiózł ze sobą listy od Jana do jego przyjaciót ${ }^{60}$. Sama podróż do Kukuzus była jednak dla Jana mordercza, choć był witany owacyjnie przez miejscową ludność i niższe duchowieństwo; gorzej było z biskupami, którzy często okazywali mu wręcz otwartą wrogość, jak to było chociażby z biskupem Ancyry Leoncjuszem, który miał Janowi nawet grozić śmiercią, jeśli ten pośpiesznie nie wyruszy w dalszą drogę ${ }^{61}$ oraz Farentiọsem, biskupem Cezarei Kapadockiej, który mimo początkowo okazywanej Janowi sympatii, potem również z wrogością

\footnotetext{
53 Ibidem., 20, 143-154.

54 Joannes Chrysostomus, Epistola, 121, PG 52, 676.

55 Por. idem, Epistolae 13-14, PG 52, 610-611.

56 Por. idem, Epistolae 10 et 121, PG 52, 608 et 732.

57 Por. idem, Epistolae 8-9, PG 52, 607-607.

${ }^{58}$ Por. idem, Epistolae 179 et 226, PG 52, 713 et 736.

${ }^{59}$ Por. idem, Epistolae 10-11, PG 52, 608-610.

${ }^{60}$ Por. idem, Epistolae 11 et 115, PG 52, 609 et 672.

${ }^{61}$ Por. idem, Epistola 14, 1, PG 52, 613.
} 
odniósł się do wygnańca i to do tego stopnia, iż ten trapiony wysoką gorączką musiał opuścić schronisko w Cezarei po tym, jak miejscowy biskup kilkakrotnie wysyłał tam mnichów, którzy zagrozili, iż podpalą je, jeśli Jan natychmiast nie opuści miasta. Sprawa była do tego stopnia poważna, iż nawet eskortujący żołnierze nie mogli nic zdziałać w obliczu agresywnych zachowań mnichów. Nic nie uczynił także miejscowy prefekt, który najprawdopodobniej obawiał się popaść w niełaskę stolicy, w przypadku gdyby stanął w obronie wypędzonego biskupa ${ }^{62}$. Tak więc Jan, zmuszony do opuszczenia Cezarei, udał się do majątku bliżej nieznanej Seleucji, znajdującego się w okolicach Cezarei, skąd również musiał wkrótce pośpiesznie uciekać, kiedy wytropili go tam mnisi ${ }^{63}$. W tym samym liście, w którym Jan opisuje swe doświadczenia w Galacji i Cezarei, kolejny raz formuje stwierdzenie, iż padł ofiarą nagonki biskupów, dodając, iż to ich właśnie musiał się bardziej obawiać, niż Izauryjczyków; to biskupi, nawet na wygnaniu, nie dawali mu spokoju ${ }^{64}$. W końcu, po ponad dwóch miesiącach wędrówki, Jan dotarł do Kukuzus, miejsca swej zsyłki $^{65}$.

Z korespondencji Jana wynika, iż w jego przypadku sam fakt wygnania nie był najgorszą rzeczą, jaka go spotkała: o wiele gorszym było znoszenie trudów podróży. Do tego bowiem stopnia podróż do Kukuzus go wyczerpała, iż pisał do swych przyjaciół w stolicy, aby nie zabiegali o zmianę miejsca jego wygnania. Zauważa on również, iż każde nowe miejsce może być gorsze od tego, w którym aktualnie przebywa, a poza tym nie zniósłby już trudów podróży. Sam stwierdza, iż podróż, którą właśnie odbył, o mało nie przyprawiła go o śmierć. Dlatego też prosił Olimpiadę, aby nie zabiegała o zmianę miejsca jego wygnania, chyba, że w grę wchodziłaby któraś z miejscowości nadmorskich, jak Kyzikos lub okolice Nikomedii ${ }^{66}$. Ta ostatnia prośba świadczy o tym, jak Jan był dalece niezorientowany w sytuacji, myśląc, iż miejscem jego zesłania mogłyby być okolice bityńskiej Nikomedii położonej tak blisko stolicy.

\section{MIEJSCE ZSYŁKI}

W przypadku wyroku skazującego na wygnanie istotnym bylo umieszczenie biskupów z dala od środowiska, w którym cieszyli się poparciem, by odległość ta, jeśli nie uniemożliwiała, to przynajmniej ograniczyła im możliwości kontaktowania się ze swymi wiernymi. W tym celu wybierano te zakątki Im-

62 Por. idem, Epistolae 14, 1-2 et 120. PG 52, 613 et 674.

63 Por. idem, Epistola 14, 2, PG 52, 613.

${ }^{64}$ Por. idem, Epistola 14, 4, PG 52, 617.

65 Por. idem, Epistola 234, 2, PG 52, 739.

${ }^{66}$ Por. idem, Epistola 13, PG 52, 610-612; zob. także Epistolae 193, 204, 220. 
perium, które często nie były jeszcze schrystianizowane lub też, gdzie istniały niewielkie społeczności chrześcijańskie, odcięte jednak od świata sporów doktrynalnych. Otwartą kwestią, ze względu na brak przekazów źródłowych, pozostaje problem utrzymania $\mathrm{w}$ tajemnicy miejsca zsyłki. Źródła niestety w żadnym z przypadków nie precyzują, czy informacje te podawano do publicznej wiadomości, kiedy decyzję skazującą na wyganie dotychczasowego pasterza odczytywał na agorze specjalny wysłannik cesarski. Skoro jednak starano się zsyłać biskupów w najodleglejsze i najdziksze zakątki Imperium, aby uniemożliwić im jakikolwiek kontakt ze stronnikami, można przyjąć, iż samo miejsce zsyłki również utrzymywano w tajemnicy. Jednakże wieść o miejscu zsyłki rozchodziła się, kiedy przez poszczególne prowincje podążał do niego wygnany biskup.

Praktyka skazywania biskupów na wygnanie przez cesarzy chrześcijańskich została zapoczątkowana na Soborze Nicejskim, kiedy to na wygnanie skazani zostali Euzebiusz - biskup Nikomedii oraz Teogonis - biskup Nicei, którzy nie zgadzali się na potępienie Ariusza ${ }^{67}$. Atanazy na swe pierwsze wygnanie został zesłany do Trewiru w Galii ${ }^{68}$. Paweł, biskup Konstantynopola, po pierwszym swym wydaleniu w 337 roku zbiegł na Zachód ${ }^{69}$, na drugie zaś zesłanie trafił do Tessalonik, mając przy tym możliwość, jak utrzymuje Sozomen, przemieszczania się po Ilyrii, przy jednoczesnym zakazie wstępu do prowincji wschodnich, co wydaje się jednak mało prawdopodobne ${ }^{70}$; na trzecie i ostateczne wygnanie Paweł udał się do Kukuzus w Armenii ${ }^{71}$.

Eustacjusz, biskup Antiochii deponowany na synodzie antiocheńskim w 330 roku, zesłany został do Trajanopolis w Tracji (jak utrzymuje Euzebiusz z Cezarei $^{72}$ ) lub też do jednego $\mathrm{z}$ miast Ilyrii, jak podaje to Teodoret $\mathrm{z}$ Cyru ${ }^{73}$. Eudoksjos, biskup Antiochii (w latach 358-359), trafił do Arabissos, skąd jednak powrócił i zasiadł na tronie biskupim w Konstantynopolu ${ }^{74}$; Asteriusz, biskup Petry wygnany został przez Walensa do Górnej Libii ${ }^{75}$; Melecjusz, biskup Antiochii na swe pierwsze wygnanie skazany został przez Kon-

${ }^{67}$ Por. Theophanes, Chronographia, AM 5816; Sozomenus, HE I 21.

${ }^{68}$ Por. Athanasius, Apologia contra arianos 3, 29, 87; Theophanes, Chronographia, AM 5827; Sozomenus, HE II 28; III 2; Socrates, HE I 35; Theodoretus, HE I 31; H. Drake, op. cit., s. 193-204.

${ }^{69}$ Por. Socrates, HE II 7; Sozomenus, HE III 5.

70 Por. Sozomenus, HE III 9.

71 Por. Theophanes, Chronographia, AM 5849; Athanasius, De fuga sua 3; Theodoretus, HE II 5; Sozomenus, HE IV 2; Photius, Bibliotheca cod. 257. Inaczej poniewierkę Pawła przedstawia Atanazy (Historia Arianorum 7), który utrzymuje, że Paweł został zesłany przez Konstantyna Wielkiego do Pontu; Konstancjusz natomiast zesłał go do Singary w Mezopotamii. Stamtąd trafił on do Emezy i w końcu do Kukuzus.

72 Por. Eusebius, Vita Constantini III 39.

73 Por. Theodoretus, HE I 21-22; Theophanes, Chronographia, AM 5818.

74 Por. Philostorgius, HE IV 8.

75 Por. Athanasius, Historia Arianorum 18. 
stancjusza II do Armenii, skąd zresztą pochodził ${ }^{76}$; biskupi-uczestnicy synodu w Rimini (359-360), którzy podpisali potępienie duchownych ariańskich, trafili do Tracji; Eustacjusz, biskup Antiochii, wygnany przez Walensa w 369 roku, trafił do miasta Bizya w Tracji ${ }^{77}$. Na wygnanie w czasach Walensa do Tracji skierowany został również Euzebiusz, biskup Samosaty ${ }^{78}$. Szesnastu biskupów Egiptu i Libii, krótko po 356 roku, mimo braku cesarskiego rozkazu skazującego ich na wygnanie, nadgorliwi arianie wysłali pod strażą w różne zakątki pustyni: biskupi libijscy trafili do Wielkiej Oazy, biskupi Tebaidy natomiast do Libii $^{79}$. Później jedenastu biskupów egipskich, stronników patriarchy Aleksandrii Piotra, za odmowę przystąpienia do wspólnoty z ariańskim biskupem Lucjuszem ok. 375 roku trafiło na wygnanie w okolice Diocezarei w Palesty$n^{80}{ }^{80}$.Za sprawą Nestoriusza na wygnanie do Famothin w Egipcie trafił Aleksander, biskup Hierapolis ${ }^{81}$. Eunomiusz na swe pierwsze wygnanie w czasach Walensa trafił do Frygii ${ }^{82}$. Później Teodozjusz I zesłał go do Halmyris nad Dunajem, skąd na skutek gockiego zagrożenia został przeniesiony do swego majątku Dakora w Kapadocji ${ }^{83}$. Nie znamy natomiast miejsca zsyłki, do którego trafił Flawian, pasterz Konstantynopola, pozbawiony na „zbójeckim” synodzie efeskim (449) tronu biskupiego. W każdym razie skazaniec zmarł w Epipie, niewielkim miasteczku Lidii, które najprawdopodobniej nie było jednak miejscem zsyłki, ze względu na niewielką odległość od stolicy ${ }^{84}$. W 449 roku na zsyłkę do Petry poszedł również jeden ze stronników Nestoriusza, biskup Tyru Ireneusz ${ }^{85}$. Deponowany na Soborze Chalcedońskim Dioskur został zesłany do Gangry w Paflagonii ${ }^{86}$.

Palladiusz opisując pobyt Jana na wygnaniu przekazuje również wiele informacji na temat losów jego stronników: Cyriak, biskup Emezy, trafił do Palmyry (zaledwie 80 mil od Emezy); Eulysius, biskup syryjskiej Bostry, zesła-

${ }^{76}$ Por. Theodoretus, HE II 32; zob. R. Snee, Valens'Recall of the Niceane Exiles and Anti Arian Propaganda, „Greek, Roman and Byzantine Studies” 26(1985), s. 414. Melecjusz trafił na wygnanie również za panowania Walensa (Socrates, HE IV 2; Sozomenus, HE VI 7).

${ }^{77}$ Por. Socrates, HE IV 15; Sozomenos, HE VI 13.

78 Por. Theodoretus, HE IV 13-14; Theophanes, Chronographia, AM 5864.

79 Por. Athanasius, Apologia ad Constantium imperatorem 27 et 32; idem, De fuga sua 6-7; Theodoretus, HE II 14; zob. także E.R. Hardy, Christian Egypt: Church and People. Christianity and Nationalism in the Patriarchate of Alexandria, New York 1952, s. 63.

${ }^{80}$ Por. Theodoretus, HE IV 22; Epiphanius, Panarion, LXXII 10, 4-12; Palladius, Historia Lausiaca 46, 3.

81 Por. Synodicon, PG 84, 803.

82 Por. Gregorius Nyssenus, Contra Eunomium I, PG 45, 257-260.

83 Por. Sozomenus, HE VII 17.

${ }^{84}$ Por. Breviculus historiae Eutychianistarum, cyt. za C. J. Hefele, op. cit., Bd. II, s. 366. Inaczej uważa K. Ilski (Sobory w polityce religijnej Teodozjusza II, Poznań 1992), s. 22-23, przypis 71.

85 Por. Theodoretus, Epistola 110; Evagrius, HE I 10.

86 Por. Nicephorus Callixtus, HE XV 5, PG 146; Evagrius, HE II 5, 11; Zacharias, HE III 2. 
ny został do graniczącej z Saracenami twierdzy Misphas, trzy dni drogi od Bostry; Demetriusza, biskupa Pessinos, zesłano do Wielkiej Oazy w Egipcie; Palladiusz, biskup Hellenopolis trafił do egipskiego Syene; inny ze stronników Jana, Serapion - metropolia Heraklei, po doświadczeniu wielu cierpień w więzieniu zesłany został do Egiptu, skąd zresztą pochodził; Hilarios, pasterz nie określonego przez Palladiusza miasta, zesłany został do Pontu ${ }^{87}$. Informacje o zsyłkach zwolenników Jana podane przez Palladiusza znajdują potwierdzenie w ówczesnym ustawodawstwie cesarskim. Dochowało się bowiem do naszych czasów rozporządzenie cesarza Arkadiusza, nakazujące zesłanie na wygnanie zdeponowanych stronników Jana do miejsc odpowiednio oddalonych od ich siedzib ${ }^{88}$. Wielu stronników Jana zdołało zbiec i ukryć się w bezpiecznych miejscach ${ }^{89}$. W sumie według Palladiusza na zesłanie trafiło 40 biskupich zwolenników Jana, co wydaje się być raczej liczbą przesadzoną ${ }^{90}$. Natomiast stronnicy Jana, którzy wstąpili do wspólnoty z biskupem Arasacjuszem, zostali przeniesieni na biskupstwa w Tracji ${ }^{91}$.

Biskupi skazywani na wygnanie zmieniali niekiedy miejsce swego pobytu, a to najczęściej za sprawą swych adwersarzy, którzy uważali, że albo wygnaniec zdobył w miejscu swej zsyłki zbyt wielką popularność albo przyciągał do siebie nazbyt wielu stronników; czasami również samo miejsce zsyłki okazywało się niezbyt odległe. Wielokrotnie, jak wiemy, miejsce swego wygnania zmieniał Barses, biskup Edessy, skazany na wygnanie przez Walensa: najpierw trafił na wyspę Aradus (naprzeciwko wybrzeża fenickiego?), kiedy jednak zaczął wokół siebie gromadzić coraz więcej zwolenników, zesłano go do Oxyrynchos w Egipcie. Kiedy i tam, w ludnym jak na Egipt mieście, znowu zaczął gromadzić wiernych, zesłano go do fortu Pheno, na granicy z Nubią ${ }^{92}$. Podobnie za Teodozjusza I, Eunomiusz najpierw trafił do Halmyris nad Dunajem, a potem na skutek gockiego zagrożenia, przeniesiono go do Dakory w Kapadocji ${ }^{93}$.

Najbardziej znany jest chyba jednak przypadek Jana Chryzostoma, który na pierwsze wygnanie miał trafić do Hieron w Poncie ${ }^{94}$, lecz cofnięto go $\mathrm{z}$ tej wywózki na skutek zaistniałych wówczas okoliczności (rozruchy w Konstanty-

${ }^{87}$ Por. Palladius, Dialogus 20, 35-63.

88 Por. CTh, XVI 2, 35.

${ }^{89}$ Informacje na ten temat por. Palladius, Dialogus 20, 63-67.

${ }^{90}$ Ibidem, 2 et 11, 5 i nn. Faktem jednak jest, iż Jan przed „batalią” z Teofilem cieszył się poparciem czterdziestu biskupów, por. J.H.W.G. Liebeschuetz, The Fall of John Chrysostom, w tegoż: From Diocletian to the Arab Conquest: Change in the Late Roman Empire, Leiden 1990, IV, s. 11; zob. też rozporządzenie wymierzone przeciwko stronnikom Jana, którzy odmawiali wspólnoty z Arsacjuszem (CTh, XVI 4, 6, 404 rok).

91 Palladius, Dialogus, XX, 63-67.

${ }^{2}$ Por. Theodoretus, HE IV 16; Theophanes, Chronographia, AM 5866.

${ }^{93}$ Por. Sozomenus, HE VII 17; Philostorgius, HE X 6.

94 Por. Theodoretus, HE V 34. 
nopolu, trzęsienie ziemi i przedwczesny poród cesarzowej). Na drugie wygnanie zesłano go do Kucuzy w Armenii ${ }^{95}$; zanim jednak tam dotarł, przez pewien czas przebywał pod strażą w Nicei. W końcu pod eskortą żołnierzy wywieziono go do Kukuzus, według Palladiusza „małej oddalonej od skupisk ludzkich miejscowości w Armenii, która ciągle dniami i nocami narażona była na napady Izauryjczyków"96. Sam Chryzostom natomiast o miejscu swego wygnania pisał: „Mieszkamy w miejscu całkowicie opuszczonym i bardziej bezludnym niż jakiekolwiek miejsce na ziemi" "97. Przebywając zaś w Kukuzus, Jan miał korzystać z gościny miejscowego biskupa Adelfiosa ${ }^{98}$. W Kukuzus Jan przebywał przez rok, po czym - jak stwierdza Palladiusz - jego adwersarze postanowili przenieść go do Arabissos ${ }^{99}$, co jednak nie do końca odpowiada prawdzie: Jan rzeczywiście trafił do Arabissos, ale nie na skutek zabiegów swych przeciwników, lecz uciekając z Kukuzus przed Izauryjczykami ${ }^{100}$. W Arabissos, do czasu gdy utrzymywało się zagrożenie izauryjskie, przebywał w twierdzy, i to najprawdopodobniej o tamtejszych warunkach pisze w jednym ze swych listów, iż budynek w którym przyszło mu mieszkać, był „gorszy od najpodlejszego więzienia" ${ }^{01}$. Kiedy już ustąpiło zagrożenie izauryjskie, Jan przeniósł się do rezydencji miejscowego biskupa Otreiosa, który troszczył się o cherlawego wygnańca $^{102}$. Za sprawą jednak Seweriana z Gabali, Porfyriusza - biskupa Antiochii i innych biskupów Syrii, zmieniono jeszcze raz miejsce jego zsyłki: tym razem miał trafić do Pityus nad Morzem Czarnym, ale jak pamiętamy, w drodze do niego, w pobliżu miejscowości Kommana, zmarl ${ }^{103}$.

Wielokrotnie zmieniano również miejsce wygnania Nestoriusza. Teodozjusz II zgodził się wprawdzie na depozycję Nestoriusza, jednakże pod warunkiem, iż nie trafi on na wygnanie i będzie mógł przebywać w swym macierzystym klasztorze w okolicach Antiochii ${ }^{104}$. Przebywał tam przez cztery lata ${ }^{105} \mathrm{i}$, jak sam stwierdza w Księdze Heraklidesa, z wszystkim honorami przysługującymi patriarsze $^{106}$. Po czterech latach jednak, za sprawą biskupa Antiochii

\footnotetext{
95 Por. Palladius, Dialogus 3, 39; Sozomenus, HE VIII 22; Theophanes, Chronographia, AM 5898.

96 Palladius, Dialogus 11, 5, PG 47, 36.

97 Joannes Chrysostomus, Epistola 30, PG 52, 628.

98 Por. idem, Epistolae 6, 9, 17, 127, 131.

99 Por. Palladius, Dialogus 11, 66-68.

${ }^{100}$ Por. Joannes Chrysostomus, Epistolae 127, PG 52, 687; 61, PG 52, 642; 69, PG 52, 646.

101 Epistola 69, PG 52, 646.

102 Por. Epistola 126, PG 52, 685-687.

103 Por. Socrates, HE VI 21; Sozomenus, HE VIII 28; Theodoretus, HE V 34.

104 Por. Evagrius, HE I 7; L. Abramowski, Zur „Tragödie” des Nestorius, ZKG 47(1928) s. 319. Nestoriusz cieszył się sporym poparciem cesarza Teodozjusza, zob. L.I. Scipioni, Nestorio e il concilio di Efeso, Milano 1974, s. 231; K. Ilski, op. cit., s. 11 i nn.

105 Por. Evagrius, HE I 7; L. Abramowski, op. cit., s. 319; K. Ilski, op. cit., s. 41.

106 Por. Abramowski, op. cit., s. 319.
} 
Jana $^{107}$, Nestoriusz został zesłany najpierw do Petry w Arabii ${ }^{108}$ a później do Wielkiej Oazy ${ }^{109}$. Przebywając tam na wygnaniu został uprowadzony jako jeniec podczas jednego z najazdów nadgranicznego plemienia Blemmiów; z niewoli tej, jak sam zresztą się dziwił, został następnie wypuszczony i przez pewien czas przebywał $\mathrm{w}$ różnych miejscach, między innymi w Panopolis w Tebaidzie, w Oazie Ibisa oraz w Elefantynie ${ }^{110}$.

Miejsce wygnania zmieniano również Tymoteuszowi Kotowi. Po siedmiu latach pasterzowania w Aleksandrii poszedł on na wygnanie najpierw do Gangry w Paflagonii ${ }^{111}$. Zanim jednak tam trafił, przebywal przez pewien czas w forcie Tafosirion w pobliżu Aleksandrii, dokąd, wedle relacji anonimowego autora Żywota Piotra Iberyjczyka, został wywieziony przez dowódcę wojskowego Dionizosa, który utrzymywał, iż był to jedyny sposób na uspokojenie nastrojów w mieście; w rzeczywistości jednak motywem jego działania była otrzymana zapłata od poprzednika Tymoteusza na tronie biskupim w Aleksandrii - Proteriosa ${ }^{112}$. Według Zachariasza, Tymoteusza transportowano przez Peluzjum, Palestynę aż do „morza fenickiego” i dalej do Gangry. Za sprawą chalcedończyków (w tym przede wszystkim stołecznego pasterza Gennadiusza), Tymoteusz został przeniesiony do Cherzonesu. O zesłanie Tymoteusza do Cherzonesu zabiegał również biskup Gangry, który miał już dość obecności kłopotliwego zesłańca w swym mieście ${ }^{113}$.

Miejsce wygnania zmieniano również mniej znaczącym biskupom, jak chociażby Palladiuszowi, który najpierw trafił do Syene, a później, najprawdopodobniej na skutek najazdu Blemmiów, przeniesiono go do Antinoe, gdzie spędził cztery, prawdopodobnie ostatnie lata swego wygnania ${ }^{114}$. W przypadku wielu biskupów wiemy tylko, iż zostali skazani na wygnanie. Źródła nie precyzują jednak miejsc, do których trafiali zesłańcy. W interesującym nas okresie wielu ze skazanych na wygnanie biskupów trafiło do kamieniołomów i kopalń $^{115}$. Można jednak przypuszczać, iż trafiali tam mało znaczący biskupi.

107 Por. Ibidem, s. 320; Evagrius, HE I 7.

108 Por. Acta Conciliorum Oecumenicorum (=ACO), ed. E. Schwartz, t. I, I, 3 (Concilium Universale Ephesinum), Berolini et Lipsiae 1927, s. 67; K. Ilski, op. cit., s. 60.

109 Por. Evagrius, HE I 7; Theophanes, Chronographia, AM 5925; ACO I, 3. 67-70; L. Abramowski, op. cit., s. 374; zob. także, CTh XVI 5, 66.

${ }^{110}$ Por. Evagrius, HE I 7.

111 Por. Zacharias, HE IV 7; Vita Petri Iberi 70.

112 Por. Vita Petri Iberi 67.

113 Por. Zacharias, HE IV 9; et 11. Na ten temat zob. W.H.C. Frend, The Rise of Monophysite Movement, Cambrigde 1972, s. 155-163.

114 Por. Palladius, Historia Lausiaca (=HL) 58, 1.

115 Por. Sozomenus, HE VI 38. Sozomen mówi tu najprawdopodobniej o stronnikach ortodoksyjnego biskupa Aleksandrii Piotra, którzy zostali skazani na wygnanie przez Walensa. W tym przypadku jednak, miejscem zsyłki nie mogły być okolice Diocezarei, dokąd jak wiemy od Palladiusza (HL, 46, 3), trafiło wielu egipskich stronników Piotra, gdyż Palestyna w 2. poł. IV wieku nie 
Do kamieniołomów natomiast trafiali często niżsi duchowni, współpracownicy wygnanego biskupa ${ }^{116}$.

\section{WARUNKI POBYTU BISKUPÓW NA WYGNANIU}

Nie posiadamy nazbyt wielu informacji dotyczących warunków bytowania biskupów na wygnaniu. Najczęściej, tylko w odniesieniu do najbardziej znanych przypadków, dysponujemy pewnymi informacjami. Według Atanazego, biskupów przebywających na wygnaniu (a ma on tu na myśli swych stronników zesłanych do egipskich oaz) zaopatrywano najczęściej w żywnośćc ${ }^{17}$. Niektórzy spośród biskupów mogli liczyć na pomoc materialną ze strony bogatych matron, jak Melanii Starszej czy Olimpias ${ }^{118}$. Pewne informacje źródłowe pozwalają również na stwierdzenie, iż w niektórych przypadkach zesłani na wygananie biskupi mogli liczyć na wsparcie finansowe państwa ${ }^{119}$.

Sporo informacji na temat warunków pobytu na wygnaniu pozostawił nam Jan Chryzostom w swych listach. Jego to, przebywającego na wygnaniu, odwiedzali i przez pewien czas z nim przebywali w Kukuzus dwaj jego kapłani: Konstancjusz i Ewethius ${ }^{120}$. Wielu również innych duchownych konstantynopolitańskich wyrażało chęć odwiedzenia go na wygnaniu, skoro tylko wypuszczeni zostaną z więzienia, dokąd trafili na skutek rozruchów towarzyszących jego wywózce na wygnanie ${ }^{121}$. Chryzostom przebywając w Kukuzus gościł u miejscowego biskupa Adelfiosa, korzystając również często z pomocy bliżej nam nie znanego Dioskura, najzamożniejszego mieszkańca tych okolic $^{122}$. W miasteczku tym, znajdował się, według Jana, niewielki garnizon wojskowy $^{123}$, brakowało jednak lekarzy oraz nie można było kupić najbar-

była obszarem jurysdykcji biskupów Aleksandrii. Kapłan Mojżesz, którego dotyczy interesująca nas relacja Sozomena, nie chciał być ordynowany na urząd biskupi „Saracenów” przez ariańskiego biskupa Aleksandrii Lucjusza. Dlatego też po sakrę biskupią, za cesarskim przyzwoleniem, udał się do biskupów przebywających na wygnaniu w kopalniach. Być może więc chodzi tu o kopalnie znajdujące się na Synaju? Według Atanazego (Apologia contra arianos 43) na synod w Sardyce przybył pewien biskup, który przywiózł ze sobą kajdany, którymi był skuty w czasie swej przymusowej (co oczywiście wcale nie znaczy, że wykonywanej w kamieniołomach czy kopalni) pracy na wygnaniu. O pętaniu duchownych gnanych na wygnanie por. Athanasius, Historia Arianorum 69.

${ }_{116}$ Por. Theodoretus, HE IV 22; Athanasius, Historia Arianorum 59.

117 Por. Athanasius, Apologia contra arianos 87.

118 Por. Palladius, HL, 46, 3; Sozomenus, HE VIII 27.

119 Tak miało być w przypadku biskupa Rzymu Liberiusza, którego cesarz Konstacjusz II zesłał do Beroi w Tracji (Theodoretus, HE II 16). Być może o wsparciu wygnańców ze strony państwa świadczy również jeden z listów Chryzostoma (por. Epistola 217).

120 Por. Epistola 114, PG 52, 670.

121 Por. Ibidem.

122 Por. Epistolae 13-14.

123 Por. Epistola 13, PG 52, 610. 
dziej potrzebnych rzeczy. Uciążliwy był również dla niego klimat ${ }^{124}$. Jana wspierało materialnie na wygnaniu w Kukuzus wiele znanych ówcześnie kobiet, jak: Olimpias, Syncletis lub Carteria, które przesyłały mu nie tylko pieniądze, lecz również lekarstwa i inne niezbędne rzeczy ${ }^{125}$. W Kukuzus przebywał Jan przez rok ${ }^{126}$, a później uciekając przed Izauryjczykami trafił do Arabissos ${ }^{127}$.

$\mathrm{O}$ warunkach pobytu Nestoriusza na wygnaniu dowiadujemy się z napisanego przez niego na wygnaniu pisma znanego pod tytułem Księga Heraklidesa, w której tak oto opisuje miejsce, swego zesłania: „Ci którzy doprowadzili do naszego wygnania, zgotowali nam jak najcięższy los, zsyłając nas do miejsca doświadczonego brakiem wody i trapionego ciągłą biedą. Uskarżamy się również na brak żywności" "128. Niektórzy spośród biskupów idąc na wygnanie brali ze sobą człowieka do posługi. Tak było chociażby w przypadku Cyriaka, biskupa Emezy oraz Palladiusza, który idąc na wygnanie wziął ze sobą sługę, którego jednak eskortujący go (i innych biskupów) żołnierze odebrali mu, aby im usługiwał ${ }^{129}$.

Biskupi przebywający na wygnaniu utrzymywali kontakt ze światem zewnętrznym. Świadczy o tym między innymi zachowana korespondencja oraz relacje historyków kościelnych. Jaka była tematyka tej korespondencji? Trudno sobie wyobrazić, jak to utrzymują historycy kościelni, aby były to listy pisane do wiernych, którym zesłańcy do niedawna jeszcze pasterzowali. Te z pewnością nie byłyby czytane zgromadzonym w kościele za rządów następcy wygnańca. Zesłańcy pisali natomiast listy do pojedynczych wiernych, osób dobrze sobie znanych, pytając o los swych owieczek i polemizując często z duchownymi głoszącymi według nich heretyckie poglądy ${ }^{130}$.

Problem kontaktów zesłanego biskupa najlepiej rozpatrywać na przykładzie powstałej na wygnaniu korespondencji Jana Chryzostoma. Według Ch. Baura, Jan przebywajac na wygnaniu wysłał 55 listów do różnych kobiet - diakonis lub arystokratek ${ }^{131}, 43$ listy do biskupów (z czego 29 adresowanych imiennie, a 14 grupowo), list do biskupa Rzymu Innocentego oraz innych biskupów Zachodu. Wiele listów napisał również do prezbiterów, diakonów

124 Por. Epistola 146, PG 52, 698-699.

125 Por. Sozomenus, HE VIII 27; Palladius, Dialogus 11; Joannes Chrysostomus, Epistolae 4, 1, PG 52, 590 et 232, PG 52, 738. Na temat konstantynopolitańskich przyjaciół Jana Chryzostoma zob. W. Meyer, Constantinopolitan women in Chrysostom's circle, VigCh 53(1999) 265-288.

126 Por. Palladius, Dialogus 11.

127 Por. Joannes Chrysostomus, Epistola 69, PG 52, 646.

128 Por. L. Abramowski, Zur „Tragödie” des Nestorius, art. cyt. s. 321; zob. też P. Bedian, Nestorius, Le livre d'Héraclide de Damas, Paris-Leipzig 1910.

${ }^{129}$ Por. Palladius, Dialogus, XX, 120-123.

130 Por. Zacharias, HE IV 11.

131 Por. m. in. listy do konstantynopolitańskich diakonis: Pentadii (Epistolae 94, 104, 185), Amprucli (Epistola 96); Asyncritii (Epistolae 39, 60, 77, 99); Chalcidii (Epistolae 60, 76, 98). 
i mnichów ${ }^{132}$ oraz do urzędników państwowych, jak chociażby do cubiculariusa (eunucha) Brissona, który jednak nie chcąc popaść w niełaskę dworu, nie odpowiadał na jego listy ${ }^{133}$. Przebywając w Kukuzus podtrzymywał także kontakt ze swymi stronnikami: Palladiuszem ${ }^{134}$, Tranquilliusem ${ }^{135}$ oraz Teodorem, biskupem kapadockiej Tyany ${ }^{136}$. Nieco gorzej było na początku pobytu w Arabissos. W powstałej wówczas korespondencji Chryzostom uskarżał się, iż urwał mu się kontakt z osobami, z którymi korespondował w czasie swego pobytu w Kukuzus. Ale i stąd wysyłał listy do diakona Teodota ${ }^{137}$ i do Elpidiusza, biskupa Laodycei ${ }^{138}$. Kiedy później rozniosła się wieść, iż Jan przebywa w Arabissos, zaczęły podążać do niego swoiste pielgrzymki: odwiedziło go wówczas wielu Antiocheńczyków, między innymi diakon tamtejszego Kościoła, bliżej nam nie znany Teodoret ${ }^{139}$, a także bliżej nie znany nam biskup Seleucos ${ }^{r 40}$. Do Arabissos przybywali również specjalni posłańcy od przyjaciół i bogatych matron, z listami i podarkami ${ }^{141}$. A więc Jan Chryzostom na wygnaniu był często i tłumnie odwiedzany przez swych sympatyków, najczęściej z Antiochii. Zjawisko to musiało przybrać spore rozmiary, skoro Palladiusz stwierdza, iż zapanowało wówczas wrażenie, jakoby „Kościół antiocheński wywędrował do Armenii" ${ }^{142}$, co oczywiście nie mogło ujść uwadze przeciwników Jana, a przede wszystkim Porfyriusza, biskupa Antiochii. O kontaktach Chryzostoma ze światem zewnętrznym w czasie jego wygnania świadczy także fakt, iż przebywając tam, nadal wywierał wpływ na akcję chrystianizacyjną prowadzoną w Fenicji, którą jako stołeczny pasterz rozpoczął, a którą później prowadzili sympatyzujący z nim duchowni ${ }^{143}$. Prowadzona przez wygnańców korespondencja miała jednak w dużej mierze przysłużyć się odwołaniu ich $\mathrm{z}$ wygnania. W tym celu pisali oni listy do wcześniej znanych im ważnych osobistości w państwie o wstawiennictwo w swojej sprawie ${ }^{144}$.

${ }^{132}$ Por. Ch. Baur, Der heilige Johannes Chrysostomus und seine Zeit, Bd. II (Konstantinopel), München 1930, s. 321-322.

133 Por. Joannes Chrysostomus, Epistolae 190, 234.

134 Por. Epistola 113.

135 Por. Epistola 37.

136 Por. Epistola 112.

137 Por. Epistolae 69, 135.

138 Por. Epistola 138.

139 Por. Epistolae 135-136, PG 52, 693-694.

140 Por. Epistolae 37-38, PG 52, 630-631.

141 Por. Epistolae 225, 229, 230-232.

142 Palladius, Dialogus 11, PG 47, 37D.

143 Por. Ch. Baur., op. cit., Bd. II, s. 328-333. Jan wspierał postępy akcji chrystianizacyjnej również finansowo, o czym por. I. Milewski, Pieniądz w greckiej literaturze patrystycznej IV wieku (na przyktadzie pism kapadockich Ojców Kościoła i Jana Chryzostoma), Gdańsk 1999, s. 85.

${ }^{144}$ Por. między innymi: Atanazy (Apologia contra arianos 43), Jan Chryzostom (Palladius, Dialogus 1, 172-177), Nestoriusz (Zacharias, HE II 2); Dioskur (ibidem, III 1-2). 
$\mathrm{Z}$ wyżej zestawionych relacji wynika, iż przy wyborze miejsca zsyłki dla poszczególnych biskupów kierowano się dość jasnymi kryteriami: skazańca umieszczano możliwie jak najdalej od miejsca, gdzie pełnił on swe obowiązki pasterskie; dlatego to biskupów Wschodu zsyłano najczęściej do prowincji zachodnich, do Tracji, Wielkiej Oazy, fortów w Tebaidzie i Arabii, pasterzy Zachodu natomiast do odległych zakątków prowincji wschodnich albo do Tracji ${ }^{145}$. W przypadku biskupów egipskich i libijskich najczęściej zsyłano ich do Tebaidy lub Wielkiej Oazy. Czasami zamierzonym skutkiem zesłania na wygnanie tego czy innego dostojnika była jego śmierć, do której dochodziło niekiedy jeszcze w drodze do miejsca zsyłki.

Na Zachód w IV wieku duchowni ze Wschodu trafiali nie tylko jako wygnańcy, lecz również jako osoby szukające tam schronienia oraz wsparcia w swojej sprawie. W takich okolicznościach pojawiają się tam Atanazy, Paweł - biskup Konstantynopola oraz Piotr następca Atanazego na tronie w Aleksandrii ${ }^{146}$, szukający poparcia nie tylko u biskupa rzymskiego, lecz również u panujących tam cesarzy. W biskupie Rzymu oraz cesarzu Honoriuszu nadzieję na rychły powrót $\mathrm{z}$ drugiego wygnania pokładał również Chryzostom, jednak bezskutecznie.

Stosowanie praktyki wygnania biskupów miało zróżnicowane znaczenie w zależności od czasu, w którym do praktyk tych dochodziło oraz osób, które tymi represjami zostały objęte. Mogły one służyć pognębieniu jednej ze stron w sporach wewnętrzkościelnych przez partię aktualnie popieraną przez cesarza. Takim działaniem zdobywano również trony biskupie dla swych stronników. Praktyka ta miała jednak w założeniu być środkiem służącym uspokojeniu nastrojów w Kościele oraz w poszczególnych miastach targanych sporami wewnątrzkościelnymi. Choć praktykowanie zsyłek biskupich przynosiło oczekiwane efekty, gdyż zesłańcy byli wyłączani ze spraw Kościoła, to jednak nigdy nie tracili oni kontaktu ze społecznościami, którym wcześniej przewodzili.

${ }^{145}$ Biskupi Zachodu zesłani do Egiptu przez Konstancjusza II: Lucyfer - biskup Calaris, Euzebiusz - biskup Vercellae. Obydwaj trafili do Tebaidy (Sozomenus, HE V 12). Na Wschód trafił również Hilary z Poitiers (ibidem, V 14). Na wygnanie do Beroi w Tracji w czasach Konstancjusza II trafił Liberiusz, biskup Rzymu (Theodoretus, HE II 16; Theophanes, Chronographia, AM 5843).

${ }^{146}$ Por. Theophanes, Chronographia, AM 5865; Sozomenus, HE VI 19; Theodoretus, HE IV $21-22$. 


\section{THE PLACE OF EXILES OF THE EAST ROMAN BISHOPS IN THE FOURTH AND FIFTH CENTURIES}

\section{(Summary)}

The subject of the present article are the places of exile into which the east roman bishops were sent in late antiquity. In the period we are concerned about, the act of exile followed a simple procedure: firstly, the episcopal councils decided about the deposition (the bishops were deprived of their functional duties) and then the emperors officially announced it. The bishops were sent away to most remote places due West (e. g. to the Gaule), to Trace, Egyptian oases, Thebaida, Armenia, Pontus and to forts in Arabia. The article also proved to be a fruitful source of information on the journey the „convicted" bishops had and the stape of their living conditions there. A conciderable number of the bishops changed their places of exile. It was not until the emperor was dead that the bishops exiled by him, were allowed to come back. Nevertheless most of them never made it; on the account of severe weather conditions, many died either on their way to or while in exile. 